\title{
TRIBAWANA DALAM PENCIPTAAN KARYA SENI BATIK
}

\author{
Ernawati $^{1}$ (Pascasarjana Institut Seni Indonesia Yogyakarta)
}

\begin{abstract}
The purpose of this research is to find out the meaning and function of the Tribawana concept in the process of creating batik art and the creative process of creating batik art. The method used in this research is descriptive qualitative method with a Case Study approach at the Babaran Segaragunung Cultural House. The results of this study indicate that Tribawana is three dimensions of nature, namely microcosm, macrocosm and creative sources. The creative process with the Tribawana concept is a process of reviving Javanese cultural traditions. The implementation of the Tribawana concept in the creative process at the Babaran Segaragunung Cultural House consists of an understanding process in the form of shared knowledge and practice or practice. Visualization of Semen batik as an example of batik image which contains elements of the universe.
\end{abstract}

Keywords: Tribawana, Creative Process, Cement Batik Image

\section{ABSTRAK}

Tujuan dari penelitian ini adalah untuk mengetahui makna dan fungsi konsep Tribawana dalam proses berkarya seni batik dan kegitan proses kreatif penciptaan karya seni batik. Metode yang digunakan dalam penelitian ini adalah metode kualitatif deskriptif dengan pendekatan Studi Kasus di Rumah Budaya Babaran Segaragunung. Hasil dari penelitian ini menunjukkan bahwa Tribawana merupakan tiga dimensi alam, yaitu Mikrokosmos, Makrokosmos dan sumber kreatif. Proses kreatif dengan konsep Tribawana merupakan proses penyadaran kembali kepada tradisi budaya Jawa. Pelaksanaan Konsep Tribawana dalam proses kreatif di Rumah Budaya Babaran Segaragunung terdiri atas proses pemahaman dalam bentuk pengetahuan dan latihan bersama atau praktik. Visualisasi batik Semen sebagai contoh citra batik yang di dalamnya mengandung unsur tiga jagad.

Kata kunci: Tribawana, Proses Kreatif, Citra Batik Semen

\section{PENDAHULUAN}

Telah banyak dikemukakan mengenai etimologi kata bațik oleh para peneliti lain sebelumnya. Ada yang mengatakan bahwa kata bațik berasal dari kata tik, titik, 'titiktitik', karena proses mem-bațik dimulai dengan membuat titik dalam jumlah yang banyak; ada pula yang mengartikan kata bațik dengan kératabasa, yakni, mbaka sațițik, 'sedikit demi sedikit', karena proses membuat bațik memer- lukan waktu yang panjang. Menurut terminologinya batik adalah gambar yang dihasilkan dengan menggunakan alat canting dengan bahan lilin sebagai penahan masuknya warna. Sementara ketika dilakukan kajian ulang etimologi terhadap kata bațik dalam ekologi budaya Jawa oleh Manu W. Padmadipura seorang ahli Filologi dan budaya Jawa Kuno memiliki interpretasi berbeda yang menghasilkan susunan interpretasi berikut: Bațik merupakan perubahan gramatikal (fonetis) dari: pațik $\rightarrow$ bațik. Bandingkan kata lain: parěn $\rightarrow$ barěn dan masih harus dilacak lebih lanjut perubahan dari $p$ menjadi $b$. Bațik mempunyai dasar makna dari kata țikā, sehingga bațik juga mem- punyai makna gambar, lukisan yang memaparkan flora dan fauna, yang sesungguhnya menunjukkan sebuah gambaran tentang kosmologi. Bațik juga berkaitan sangat erat dengan kata 
paștika yang kedua, karena pașțika ini merupakan bahan yang dipergunakan untuk menggambar lukisan flora dan fauna dan pula kosmologi secara lebih luas. Tempat yang dipergunakan untuk menggambar dengan paștika adalah sutra- varana.

Berkaitan dengan fungsi estetis bațik dapat ditunjukkan bahwa kata bațik ini berkaitan erat dengan kompositum: rankan sphațika dan tïrthayātra. Berkaitan dengan fungsi theologis bațik dapat ditunjukkan bahwa kata bațik ini berkaitan erat dengan kompositum: meru sphațika dan yajña- pūjā (Intensif kegiatan di Rumah Budaya Babaran Segaragunung, tanggal 17-19 Juli 2017).

Dari arti batik yang mendasar memperlihatkan batik merupakan kajian yang menarik dan bersifat berkelanjutan. Selain kata batik yang unik, perkembangan dan perubahan batik yang pesat, tentu berkaitan dengan perlunya kemampuan dalam pemikiran dan proses kreatif. Akar budaya dalam proses kreatif penciptaan karya memiliki peran penting, mengingat batik sebagai salah satu identitas yang kuat dalam budaya Indonesia. Untuk mencapai pada titik tersebut, seniman maupun desainer batik tentunya perlu masukan inspirasi pada proses kreatif mereka guna memotivasi terciptanya ide desain yang baik dan berkualitas dengan konsep yang kreatif dan menarik. Mengingat karya tidak akan tercipta dari ruang kosong, akar budaya mampu menjadi inspirasi mereka dalam berkarya, mampu mengantarkan pemahaman kepada penikmat seni apa yang menjadi gagasan desain dan tujuan dari desain diciptakan.

Proses kreatif memiliki peran penting sebagai tindakan yang menyebabkan hadirnya karya seni, dan proses kreatif tidak lepas dari sesuatu yang telah ada sebelumnya. Perwujudan karya yang masih kental dengan seni tradisi dilaksanakan di Rumah budaya Babaran Segaragunung dengan menerapkan Tribawana sebagai konsep proses kreatif yang diselami dari budaya Jawa dalam karya batik kontemporernya. Salah satunya diterapkan dengan ikut tumbuh dan berkembang dalam budaya sesuai makna pada batik seratan citra Semen. Semen berasal dari kata "Semi" yang artinya tumbuh dan berkembang sebagai bagian dari hidup dan gerak. Citra Semen pada batik terlihat pada gambar meru atau gunung beserta flora dan fauna di sekitarnya (Kusrianto, : 127). Berdasarkan makna dari batik seratan citra Semen, kiranya mampu menjadi salah satu citra yang mewakili dari konsep Tribawana yang menyatukan tiga jagad, yaitu manusia, alam, dan sumber kreativitas menjadi satu kesatuan yang tidak terpisahkan.

Guna memfokuskan kasus yang sedang terjadi pada pelaksanaan konsep Tribawana pada karya seni batik, penulis memilih tempat penelitan yang sekiranya berkaitan dengan topik yang akan dibahas, yaitu Rumah Budaya Babaran Segaragunung. Lokasi ini menjadi salah satu tempat yang menarik untuk agenda studi kasus penelitian, karena membaca seni batik dari perspektif konsep budaya Jawa, yaitu Tribawana. Proses kreatif tersebut menggambarkan suatu konsep dengan prinsip penyatuan tiga jagad dan penyampaian arti untuk menunjukkan penghormatan terhadap kehidupan, ciptaan, dan alam. Selain itu, sebagai penghubung mitologi dan ekologi, salahsatu wujud cinta akan akar budaya dan sebagai pelestarian budaya tak benda (Intangible). Memperkenalkan proses kreatif kuno 'Tribawana' yang mengajarkan seorang pencipta untuk mencari sumber kreativitas di dalam diri sendiri untuk menyatu dengan alam sebagai sumber kreativitas. Kegiatan penyatuan dengan alam ini sesuai dengan pitutur luhur budaya Jawa, pada pitutur 337) tentang Ibu Bumi, Bapak Angkasa dari pandangan orang Jawa tehadap ekosistem atau lingkungan.

Berdasarkan hasil observasi dan wawancara dengan seniman dari Rumah Budaya Babaran Segaragunung didapatkan informasi bahwa budaya tradisi batik pada proses kreatif Tribawana menerapkan strateginya dengan membahas sistem simbol yang digunakan dalam batik tradisional sebagai kerangka untuk menciptakan simbol sendiri yang termasuk makna, fungsi, dan estetika. Melakukan latihan bersama dalam menggunakan rasa, pikir, dan tubuhnya sendiri untuk menyalurkan daya kreativitas. Proses lainnya pada proses kreatif, konsep 
Tribawana membahas mitologi Jawa, melakukan pendekatan terhadap proses kreativitas, melakukan pendekatan terhadap cara menyikapi batik sebagai seni budaya bukan hanya sebagai sesuatu keterampilan teknik, dan menjadikan keterampilan membatik sebagai suatu budaya yang integral.

Berdasarkan pemaparan di atas, penulis memandang sistem ilmu budaya sebagai akar atau titik penopang konstruksi di atasnya. Proses kreatif sebagai bagian dari sistem ilmu budaya yang sangat penting dalam menciptakan karya seni, dan beranggapan tanpa proses kreatif karya seni tidak akan berarti, karya seni pun tidak akan tercipta. Selain itu, konsep memiliki hubungan dengan benda seni yang tercipta. Dalam upaya menyikapi fenomena tersebut, perlu memperdalam dan melakukan upaya menyingkap konsep proses kreatif dalam menciptakan karya batik sebagai bagian dari pengetahuan yang berpegang pada prinsip penyatuan tiga jagad untuk bahan motivasi, inovasi, dan perkembangan seni kriya batik. Maka peneliti berkeinginan untuk memaparkan tentang konsep Tribawana dalam proses kreatif karya seni batik seratan citra Semen. Lebih jauh lagi ini sebagai langkah awal untuk dapat menemukan solusi dan temuan baru dalam pengembangan pengetahuan terhadap sisi pendidikan intangible batik di masa yang akan datang dengan melibatkan peran pelajar, seniman, perajin, dan guru.

Berdasarkan latar belakang masalah tersebut, penelitian ini membahas makna dan fungsi konsep Tribawana dalam proses berkarya seni batik dan seluk-beluk proses kreatif penciptaan karya seni batik di Rumah Budaya Babaran Segaragunung.

\section{Metodologi Penelitian}

\section{a. Pengumpulan Data}

Pada proses penelitian ini, peneliti mengambil topik tentang makna dan fungsi Konsep Tribawana dalam proses penciptaan karya seni batik di Rumah Budaya Babaran Segaragunung. Peneliti memilih topik tersebut, karena pentingnya batik sebagai budaya intangible untuk dibaca dan dilaksanakan dengan kembali pada akar budaya Jawa Kuno, yaitu konsep Tribawana. Oleh sebab itu, perlu membaca ulang citra batik dan praktik dalam berkarya batik berdasarkan budaya asal batik berada. Selain itu, penelitian ini merasa diperlukan sebagai bagian partisipasi untuk menjaga martabat dan kehormatan bangsa, dengan mengangkat nilai-nilai kearifan lokal.

Penelitian ini dilaksanakan di Rumah Budaya Babaran Segaragunung, dengan memilih enam orang informan. Informan yang yang ditentukan yaitu ahli filologi, ahli filsafat budaya, dan empat orang seniman. Peneliti memilih Informan dengan pertimbangan, ahli filologi sebagai informan dalam bidang sastra budaya Jawa Kuno, yang berhubungan dengan aspek bahasa Jawa Kuno pada proses membaca citra batik, ekologi Jawa dan mitologi Jawa. Ahli filsafat budaya, sebagai informan dalam konsep budaya Jawa kuno dari perspektif budaya dan aspek historis. Selanjutnya, empat orang seniman sebagai pelaku kegiatan proses kreatif dengan konsep Tribawana.

Dalam melaksanakan penelitian supaya tujuan yang diinginkan dapat tercapai, diperlukan metode penelitian yang tepat dan relevan. Hal ini diperlukan supaya tercapai analisis yang tepat. Berdasarkan hal tersebut, penelitian yang digunakan yaitu penelitian kualitatif deskriptif dengan pendekatan studi kasus. Penelitian ini memusatkan diri secara intensif pada objek tertentu yang mempelajarinya sebagai suatu kasus. Data kasus dapat diperoleh dari semua pihak yang bersangkutan, dengan kata lain dalam studi ini dikumpulkan dari berbagai sumber (Nawawi, 2003:1). Fokus kajian penelitian ini adalah makna dan fungsi konsep Tribawana pada proses kreatif penciptaan karya seni batik seratan citra Semen. Peneliti memilih pendekatan studi kasus berhubungan dengan topik penelitian tentang kasus unik yang sedang terjadi di lokasi tertentu. Selain itu, berdasar pada sifat penelitian studi kasus yang sangat mendalam, dan harapan dari pemahaman yang mendalam itu dapat diperoleh sebuah konsep atau teori tertentu untuk pengembangan ilmu pengetahuan.

Data merupakan hal yang sangat penting dalam penelitian yang diperoleh dari 
berbagai sumber data. Tahapan penelitian ini diawali dengan kegiatan pengumpulan data sesuai dengan lingkup objek penelitian dengan memusatkan perhatian pada satu objek tertentu yang diangkat sebagai sebuah kasus untuk dikaji secara mendalam, sehingga mampu membongkar realitas di balik fenomena. Perhatian penelliti difokuskan pada pengumpulan data yang berhubungan dengan makna dan fungsi konsep Tribawana dalam proses kreatif penciptaan batik seratan citra Semen di Rumah Budaya Segaragunung.

Dalam pengambilan data, langkah atau tahapan yang akan dilakukan peneliti sesuai dengan pedoman pengambilan data dalam penelitian kualitatif dengan pendekatan studi kasus yaitu sebagai berikut:

1. Observasi Partisipasi, yaitu melibatkan diri langsung dengan objek yang diteliti. Hal ini dilakukan supaya peneliti sebagai instrumen utama (key instrument) dapat merasakan objek yang diteliti dan dapat memberikan penilaian. Dalam melakukan pengamatan, peneliti membuat semacam panduan pengamatan mengenai poinpoin apa saja yang akan diamati dan membuat protokol mengenai penelitiannya.

2. Wawancara

Wawancara yang akan dilakukan oleh peneliti yaitu wawancara mendalam dengan struktur pelaksanaan semiterstruktur. Diperlukan wawancara mendalam karena peneliti studi kasus diharapkan tidak saja menangkap makna dari sesuatu yang tersurat, tetapi juga yang tersirat. Melalui wawancara mendalam, peneliti tidak begitu saja menerima informasi dari narasumber, tetapi juga memaknai ucapan-ucapannya. Peneliti sebagai instrumen utama dalam penelitian, membawa pedoman wawancara sebagai panduan wawancara dengan tipe "one on one" interview yang dilakukan terhadap narasumber yang telah ditentukan. Peneliti memilih semiterstruktur, karena memungkinkannya pertanyaan tidak persis seperti urutan pertanyaan dalam pedoman wawancara, keadaan dan situasi atau tanggapan dari narasumber terhadap topik yang dipertanyakan terkadang menjawab pertanyaan lain, sehingga peneliti sebagai pewawancara perlu berusaha menyesuaikannya.

3. Dokumentasi, yaitu pengumpulan data dan informasi tentang objek penelitian. Dokumentasi ini dilakukan dengan mengambil data yang berasal dari sumber non-manusia, yang dilakukan dengan cara mengumpulkan data sekunder. Data sekunder dalam bentuk arsip-arsip penting berupa tulisan, audio maupun video yang berhubungan dengan kegiatan di Rumah Budaya Segaragunung dan visual produk batik seratan citra Semen, digunakan untuk melengkapi data primer yang diperoleh.

4. Artefak fisik. Artefak di sini berupa studi literatur dan batik seratan citra Semen. Studi literatur berupa pengumpulan data dan pemilihan informasi sesuai kebutuhan kemudian mendeskripsikannya dalam tahapan analisis data. Pada tahap ini peneliti, menyesuaikan kembali referensi yang relevan dan mutakhir dengan topik permasalahan penelitian. Peneliti disini sebagai instrumen utama berusaha lebih menerapkan kepekaan teoritik, sehingga dapat mengoordinasikan dengan baik antara data yang sesuai dengan kajian literatur dan data sebagai temuan baru yang dapat menjadi pengembangan dari teori yang telah ada. Sedangkan batik seratan citra Semen sebagai kajian artefak dalam bentuk visual berupa struktur ornamen yang akan dibaca dengan konsep Tribawana.

Instrumen utama dalam penelitian ini yaitu peneliti sebagai alat pencari sekaligus penganalisinya. Dalam hal ini peneliti menggunakan alat tulis untuk membuat memo dan catatan lapangan selama kegiatan proses pengumpulan data. Pedoman wawancara sebagai instrumen yang ikut mengatur berjalannya proses wawancara, yaitu sebagai panduan wawancara. Kamera digital dan handphone sebagai alat rekaman suara dan pengambil gambar untuk memperjelas dan mempermudah proses transkripsi hasil wawancara. 


\section{b. Analisis Data}

Dalam penelitian ini dilaksanakan analisis data baik secara tekstual maupun kontekstual. Guna mengungkap data tersebut, peneliti melakukan langkah analisis secara deskriptif dengan cara, yakni sebagai berikut:

1. Membaca, mempelajari dan menelaah keseluruhan data yang terkumpul, baik data yang tertulis maupun visual dan mengklasifikasikannya sesuai jenis dan sifat data.

2. Mengadakan reduksi data yang dilakukan dengan jalan yaitu membuat rangkuman inti, proses, dan pernyataan-pernyataan yang perlu dijaga, sehingga tetap berada di dalamnya, membuat memo dan diagram sebagai proses pemusatan perhataian pada penyederhanaan data kasar yang muncul. Dari catatan lapangan dan transkripsi wawancara tersebut dilakukan dengan cara pengkodean secara menyeluruh.

3. Menyusun dan mengategorisasikan data berdasar pada masing-masing kategori permasalahan penelitian dalam pengkodean tahap kedua.

4. Mengadakan pemeriksaan data untuk menetapkan keaabsahan data.

5. Penafsiran (menginterpretasikan) data yang telah terseleksi dirangkai menjadi satu kesatuan analisis yang utuh untuk mencari makna yang lebih luas (holistik) dengan penulisan temuan berdasarkan pemikiran secara induktif.

\section{HASIL DAN PEMBAHASAN}

Penelitian ini ingin mengetahui dan memahami fungsi dan makna konsep Tribawana dalam proses berkarya seni batik dengan mengambil sampel citra batik Seratan Semen. Supaya dapat terjawab, peneliti melakukan penelitian dengan mengumpulkan data yang langsung dari sumbernya, yaitu di Rumah Budaya Babaran Segaragunung, dengan fokus kepada kasus proses kreatif konsep Tribawana dalam berkarya seni batik. Guna memperoleh data yang berhubungan dengan topik penelitian, peneliti menentukan subjek dan objek penelitian. Subjek penelitian ini adalah seniman batik, sejarawan, dan sejarawan budaya Jawa. Objek penelitian mencakup objek ornamen pada seratan citra Semen, pemikiran-pemikiran atau gagasan dari seniman batik. Pemilihan karya batik ditentukan yaitu desain batik seratan citra Semen. Pembatasan ini didasarkan atas masalah yang terkait dengan hubungan konsep Tribawana dalam penciptaan citra batik seratan citra Semen.

\section{a. Tribawana}

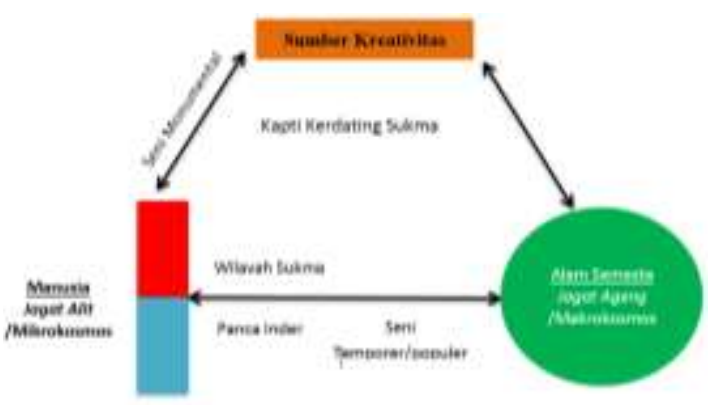

Gambar 1. Bagan Konsep Tribawana di Rumah Budaya Babaran Segaragunung

(Sumber: Digambar kembali oleh Ernawati, November 2017)

Tribawana tentang kembali kepada pemahaman pokok tentang budaya. Kroeber dan Kluckhohn ahli antropolog terkemuka, berhasil mengidentifikasi bahwa terdapat enam pemahaman pokok tentang budaya, salah satunya menyebutkan budaya dari aspek historis bahwa budaya cenderung sebagai proses yang dialihturunkan dari generasi ke generasi berikutnya. Ketika dihubungkan dengan fenomena historis, konsep Tribawana tentunya penting untuk dikaji ulang dan diterapkan pada kegiatan berkarya seni batik, sebagai wujud pelestarian budaya Jawa Kuno dalam berkarya seni. Koentjaraningrat (1985: 5-6), menyebutkan bahwa kebudayaan merupakan keseluruhan sistem gagasan, tindakan, dan hasil karya manusia dalam kehidupan masyarakat. Wujud dan isi kebudayaan, menurut ahli antropologi tersebut sedikitnya ada tiga, yaitu (1) ideas, (2) activities, dan (3) artifacts. Ketiga wujud kebudayaan tersebut oleh Koentjaraningrat dinyatakan sebagai sistemsistem yang erat kaitannya satu sama lainnya, dan dalam hal ini sistem yang paling abstrak (ideas) seakan-akan berada di atas untuk 
mengatur aktivitas sistem sosial yang lebih konkret, sedangkan aktivitas dalam sistem sosial menghasilkan kebudayaan materialnya (artifact). Sebaliknya sistem yang berada di bawah dan yang bersifat konkret memberi energi kepada yang di atasnya (Pujileksono: 36). Pendapat tersebut memberikan gambaran bahwa kebudayaan Jawa merupakan interaksi timbal-balik di antara sistem-sistem dalam wujud kebudayaan tersebut, yaitu hubungan antara ide, aktivitas dan artefak. Dari pernyataan Koentjaraningrat tersebut, Tribawana ini lebih kepada kenyataan historis tradisi kreativitas Jawa Kuno. Sedangkan untuk hasil budaya berupa artefak merupakan bukti adanya aktivitas dari sebuah gagasan (ide) masyarakatnya.

Hasil wawancara dengan Agung Harjuno seorang ahli filsafat kebudayaan menyatakan bahwa dalam terciptanya setiap karya atau artefak sebagai budaya material yang bernilai tinggi, bersifat monumental atau tidak temporer (populer), memiliki nilai-nilai tinggi dan dikuti oleh generasi berikutnya tidak lepas dari proses kreatif yang berdasarkan akar budaya itu sendiri, salah satunya budaya Jawa Kuno. Dari pernyataan tersebut, tentunya konsep Tribawana sebagai salah satu bagian dari akar budaya tersebut memiliki relevansi dan ketepatan ketika diterapkan pada proses kreatif dalam berkarya seni. Tribawana merupakan konsep kreativitas berkarya yang terdiri atas tiga dimensi alam, yaitu Jagad Alit (mikrokosmos), Jagad Ageng (Makrokosmos), dan Sumber Kreativitas. Tiga hal ini harus diterima sebagai aspek pandangan kosmologi budaya Jawa sebagaimana terdapat dalam teks Arjuna Wiwaha dengan bait pembuka manggala atau alam cahaya (dewa) atau dewa pujaan. Tribawana dapat digunaan dalam sastra dan dalam semua aspek kesenian termasuk arsitektur dan seni rupa. Salah satu bukti artefak dalam bidang arsitektur tentang Tribawana terdapat pada candi yang terbagi menjadi bagian-bagian, bagian atap candi, tubuh candi, dan bagian kaki candi. Dalam seni rupa dan kriya salah satunya ada pada batik. Dalam batik, misalnya dalam batik seratan citra Semen. Semen yang artinya dari kata semi, 'tumbuh dan hidup', dalam visualisasinya dapat mewakili tiga jagad dalam Tribawana, karena terdapat tiga unsur citra yang menggambarkan jagad mikrokosmos, jagad makrokosmos, dan sumber kreativitas. Jadi, dapat dilihat pada bagan proses kreatif Tribawana menunjukan bahwa seni yang memiliki nilai dan bersifat monumental dapat tercipta dengan mengikuti putaran atau rotasi tiga jagad, sedangkan ketika berkarya seni tidak melibatkan proses penyatuan tiga jagad karya yang akan tercipta hanya berupa seni populer yang akan hilang termakan oleh zaman.

\section{b. Konsep Tribawana dalam Proses Kreatif Berkarya Seni Batik \\ Posisi \\ peneliti dalam}

penginterpretasian temuan, pendeskripsian atau pembedahan karya maupun artefak dengan kembali kepada pohon kreativitas berdasarkan budaya Jawa kuno. Jawa menjadi lokasi tempat kembali dari aspek budaya, karena batik berasal dari sistem ilmu Jawa. Hubungan konsep Tribawana pada karya seni berkenaan dengan pedoman hidup yang diaplikasikan pada karya seni yaitu batik. Berdasarkan hal tersebut penginterpretasian ulang batik, perlu kembali kepada akar budaya tradisi Jawa kuno, yaitu Tribawana.

Dalam pelaksanaan proses kreatif di Rumah Budaya Babaran Segaragunung terdiri atas proses pemahaman dalam bentuk pengetahuan dan latihan bersama atau praktik. Kegiatan mempelajari pengetahuan tentang batik, dengan pendekatan pengetahuan budaya Jawa Kuno, yaitu dengan membaca batik berdasarkan sejarah, mitologi, ekologi, teks kakawin dan bahasa Jawa Kuno. Dari kegiatan belajar ini, diharapkan dapat memahami makna, fungsi dan estetika batik berdasarkan makna asal batik yaitu berdasarkan tradisi budaya Jawa Kuno. Proses pembelajaran ini memberikan kesadaran bahwa seni, salah satunya batik merupakan ilmu yang multidisiplin, karena di dalam proses pemahaman dan penginterpretasian visual batik melibatkan pandangan perspektif budaya, yaitu budaya Jawa Kuno, dari aspek bahasa digunakan pada proses penyampaian dan proses pembacaan teks, yaitu bahasa Sanskerta, bahasa 
Indonesia, dan bahasa Jawa Kuno. Selain itu ada pendekatan ekologi Jawa, dengan pendekatan pada alam dan lingkungan, baik dengan melihat dalam bentuk foto, video maupun dengan melihat secara langsung dan menyentuhnya. Pendekatan ekologi ini, memberikan pengetahuan baru tentang alam yang dihubungkan dengan kebudayaan Jawa, baik dari kebiasaan perlakuan orang Jawa terhadap alam, maupun bahasa atau pengenalan nama tumbuhan berdasarkan bahasa Jawa Kuno.

Proses kreatif berikutnya yaitu tahap praktik. Proses kreatif memiliki tahapan yang unik dan menarik yaitu dengan adanya proses pemanasan berdasarkan tradisi budaya yang dikenal dengan istilah Prep bagian dari proses kreatif Tribawana. Proses praktik dengan konsep Tribawana erat kaitannya dengan, konsentrasi, kontemplasi, meditasi dan semadi dengan proses penyatuan diri dengan alam. Dalam proses melewati ini, manusia atau mediator sebagai mikrokosmos ini, membawa kita kepada aspek pengenalan diri. Pengenalan diri pada aspek kreatif tidak dapat berdiri sendiri. Hal ini berhubungan dengan penyatuan diri dengan alam sekitar atau makrokosmos. Proses korelasi Mikrokosmos dan Makrokosmos ini melibatkan olah tubuh dengan gerakan tubuh, kepekaan olah rasa oleh pancaindra dan penyatuan dengan alam. Mikrokosmos dan Makrokosmos mencapai titik temu dari sesuatu yang memberi hidup yaitu Sumber Kreativitas. Pada proses ini, tentang penyatuan olah tubuh dan olah rasa dengan penghayatan penuh. Kegiatan ini mengambil metafora manusia sebagai pohon. Hal ini memberikan gambaran tentang adanya korelasi antara metafor sebagai bahasa atau perumpamaan dengan seni batik yang seakan metafora tersebut sebagai inti dari seni batik tersebut. Metafora sebagai bahasa dan perumpamaan ini selain sebagai praktik juga mampu memberikan kesadaran bahwa batik itu bukan tentang bendanya tetapi lebih kepada pengetahuan intangible, yaitu proses kreatif dalam berkarya seni.

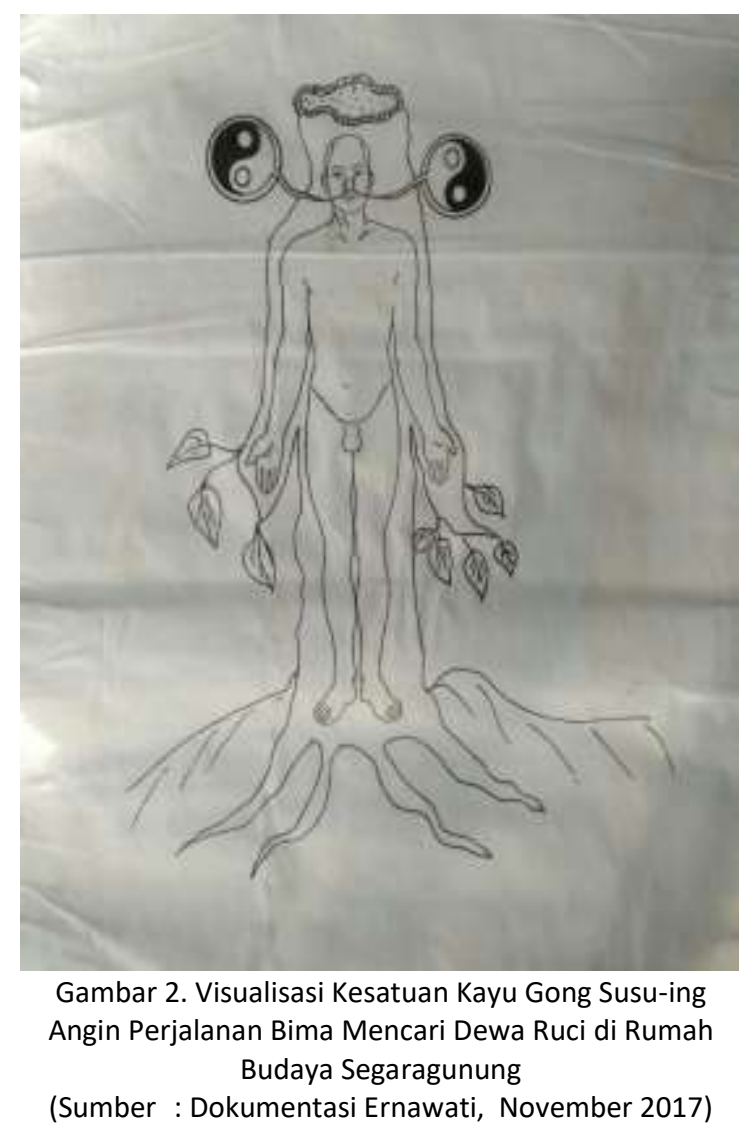

Persamaan antara manusia sebagai
pelaku seni dengan pohon, dalam visualisasinya terlihat kaki manusia yang berpijak di atas tanah atau bumi ibarat akar tanaman yang kokoh mengemban pohon di atasnya dalam pitutur luhur budaya Jawa dikenal dengan istilah Ibu Bumi. Kedua, lengan beserta jari-jemari ibarat ranting dan daundaun pohon, badan laksana tubuh pohon kokoh, dan pada wajah manusia terlihat hidung menyerap udara dari alam atau dalam budaya Jawa dikenal dengan Bapak Angkasa.

Berhubungan dengan istilah Ibu Bumi dan Bapak Angkasa termasuk ke dalam pitutur luhur budaya Jawa, dan termasuk salah satu pitutur dalam menjaga martabat dan kehormatan bangsa dengan nilai-nilai kearifan lokal. Hal ini sesuai dengan teks dalam tulisannya yang berjudul Pitutur Luhur Budaya Jawa oleh Sumodiningrat, yang menyatakan pitutur luhur Ibu Bumi, Bapak Angkasa menjadi pitutur nomor 337 dari 1001 pitutur luhur budaya Jawa. Pitutur ini memberikan pandangan orang Jawa terhadap ekosistem. Pada visualisasi pohon kreativitas di atas, terlihat jelas tergambarkan bahwa 
bumi tempat menanam, dan angkasa yang memberikan, udara air dan sinar matahari. Visualisasi tersebut seakan memberikan pesan kepada kita bahwa perlunya menjaga keharmonisan dalam ekosistem alam ini. Terjadi hubungan timbal balik saling memberi dan menerima antara bumi, angkasa, dan manusia dapat memanfaatkannya dengan bertanggung jawab. Pitutur Ibu Bumi, Bapak Angkasa juga menjadi bagian kalimat dalam panduan pada kegiatan proses kreatif praktik batik di lokasi penelitian.

Visualisasi pohon dihubungkan dengan berkarya seni batik, menggambarkan proses kreatif sama dengan menyatu dengan alam. Proses ini merupakan kesatuan antara manusia, alam, dan daya atau energi kreativitas, yang berputar dan melibatkan kedalaman rasa pelakunya. Seniman sebagai pelaku seni (Mikrokosmos) diibaratkan bagian dari alam itu sendiri (Makrokosmos). Pada pelaksanaannya, di panduan oleh satu orang seniman berupa kata-kata panduan dan diikuti oleh seniman lainnya dengan gerakan atau tindakan sesuai bunyi kata atau instruksi dari pemandu.

Pada Prep proses kreatif ini memiliki tahapan berikut: 1) Proses jalan di- tempat dalam beberapa menit, dengan gerakan bebas ada yang bergerak santai, lambat dan cepat tergantung mediator yang membawa dirinya; 2) gerakan jalan ditempat dilanjutkan dengan pelemparan lengan dengan gerakan ke kiri dan ke kanan tanpa beban, seakan bergerak dan digerakan oleh alam, tidak dipaksakan dengan dorongan emosi mediator; 3) memejamkan mata dan mulai merasakan pijakan kaki, di atas lbu Bumi, menggunakan pancaindra sesuai instruksi panduan, dengan mendengar suara di sekitar dari berbagai arah secara bertahap. Mulai dari arah kiri, kanan, depan dan belakang. Suara-suara yang hadir, pada tahap ini, laksana suara sapaan dari alam atau komunikasi diri sendiri yang ada di tengah dengan empat saudara yang berada di arah mata angin. Kemudian merasakan dengan nyaman, sentuhan angin dari Bapa Angkasa menyentuh dan menggerakkan satu demi satu jari-jemari tangan mediator; 4) mengatur nafas, dengan menarik nafas sampai habis, menyimpan dan menahannya dalam tubuh beberapa saat, kemudian dikeluarkan secara perlahan, dilakukan secara berulang; dan 5) bergumam dengan mengeluarkan suara yang riuh dengan ritme rendah kemudian secara bertahap makin tinggi dari masing-masing pesonal seniman atau mediator, sampai pada titik tertentu kemudian berteriak melepaskannya tanpa beban, dengan sampai pada titik menjadi diri sendiri. Walaupun dengan panduan yang sama tetapi menghasilkan ritme gerakan tubuh, kedalaman rasa yang berbeda dalam proses penyatuan antara diri dengan alam atau lingkungannya. Hal ini, kembali kepada mediator atau pelaku, sejauh mana dapat menyikapi, dan mengontrol dalam mengatur keseimbangan diri dan alam. Jadi, setiap seniman atau mediator akan memiliki pengalaman unik, dan tidak ada keseragaman tergantung kepada potensi diri. Walaupun dengan pengalaman rasa yang berbeda di dalamnya, tetapi pada setiap seniman atau mediator hampir sama merasakan bahwa berpikir itu tidak hanya dengan kepala saja, tetapi melibatkan kepekaan rasa dan penghayatan secara penuh dengan ikut lebur di dalamnya mampu melatih berpikir secara analitis, kritis, dan kreatif. Setelah Prep proses kreatif selesai, dilanjutkan dengan realisasi berkarya seni batik dengan menumpahkan dan menggoreskan rasa dalam diri masingmasing setelah menyatu dengan alam di atas permukaan kain.

Dalam pendeskripsiannya, setelah melaksanakan proses kreatif dalam aspek olah tubuh, rasa, dan sumber energi kreatif, keempat seniman atau mediator memiliki jawaban yang seragam yang menyatakan, " $y a$ dalam berkarya membatik mengalir begitu saja", hadir di dalamnya. Mengalir di sini, berhubungan dengan merasa lebih ringan, dinamis, dan mampu berkoordinasi dengan baik dalam proses membatik. Dalam kasus ini, karena rasa bersifat abstrak, tampaknya ada kendala dalam proses pendeskripsian tidak memiliki ukuran baku dan kepastian. Peneliti dalam menyikapi hal ini, mengambil langkah dengan menjadi partisipan dan mencoba ikut lebur dalam proses praktik konsep ini. Dari hasil pengamatan, wawancara dengan seniman dan mencoba ikut menjadi bagian di 
dalamnya, meskipun rasa bersifat abstrak, tetapi proses penyatuan tiga jagad antara manusia (Mikrokosmos), alam (Makrokosmos) dan sumber kreatif pada kenyataannya mampu melatih cara penyatuan antara, pikiran, perasaan, intuisi, tubuh, dan alam sekitar dengan titik penyampaian sumber kreatif dalam getaran yang berbeda. Lebih jauh lagi, dapat meningkatkan rasa bersyukur terhadap segala yang tercipta dan Mencipta.

$$
\text { Proses kreatif Tribawana ini }
$$
memperlihatkan bahwa batik bukan hanya tentang wujud karya, tetapi lebih mengutamakan kepada proses tradisi yang ditumbuhkan pada diri pelaku seni. Kemampuan pengendalian diri dan penyatuan dengan alam serta sumber kreativitas merupakan proses penting terhadap hasil wujud karya yang akan divisualisasikan. Hal ini tentunya sangat penting, sehubungan dengan batik sebagai kekayaaan budaya tak benda sesuai dengan pengakuan dari UNESCO. Selain itu, proses kreatif dengan konsep Tribawana sebagai upaya menggali nilai-nilai luhur budaya dan berkontribusi untuk memperkaya dan melestarikan warisan sejarah budaya.

\section{c. Tribawana dalam Batik Seratan Citra Semen}

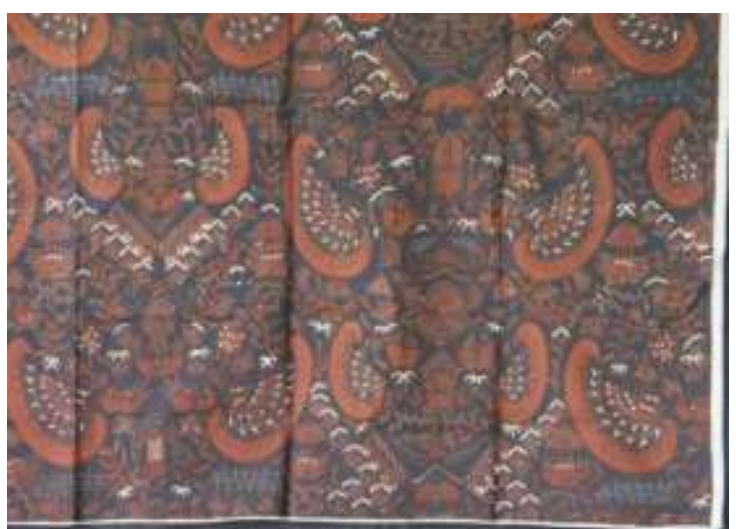

Gambar 3. Batik Seratan Citra Semen Rama karya Manu W. Padmadipura, Tahun 1997

(Sumber: Dokumentasi Manu W. Padmadipura)

Tribawana merupakan mekanisme yang dapat dikaitkan dengan semua aspek kesenian. Kembali kepada seni batik, misalnya pada batik seratan citra Semen. Dalam batik seratan citra Semen terdapat ketiga aspek: Mikrokosmos, Makrokosmos, dan sumber kreatif yang divisualisasikan. Semi memiliki arti tumbuh. Hal ini ketika dikaitkan dengan budaya tradisi budaya Jawa sama halnya dengan tradisi yang terus tumbuh dan berkembang. Dalam aspek penginterpretasian dapat menghasilkan pemaparan yang berbeda karena kondisi zaman yang berbeda, sedangkan untuk esensi batik seratan citra Semen itu sendiri sama. Dapat dikatakan sama karena, Empu sebagai pembuat karya monumental tidak mengubah esensinya. Interpretasi itu sendiri, selain dipengaruhi zaman, juga melibatkan aspek kepentingan, pemakai, dan kondisi geografis yang berbeda. Aspek tersebut merupakan getaran jiwa yang berbeda yang dapat menghasilkan karya visual yang berbeda. Keberagaman getaran jiwa tersebut tercermin pada batik seratan citra Semen yang beragam. Semen berasal dari kata semi yang berarti tumbuh dan berkembang sebagai bagian dari hidup dan gerak, mengandung meru, beserta flora dan fauna (Kusrianto, dalam Batik Filosofi, Makna dan Kegunaan: 127). Pola Semen merupakan ornamen yang menggambarkan tumbuhtumbuhan atau tanaman menjalar. Dalam citra Semen ditampilkan bentuk ornamen berupa stilasi dari alam seperti, bentuk binatang, tanaman, dan unsur-unsur lainnya. Penempatan ornamen seakan-akan tanpa ada pengaturan, terutama untuk struktur tumbuhtumbuhan, tetapi bila diperhatikan dengan seksama akan terasa visualisasi struktur ornamen seperti Lar, Rumah, Burung, Gunung, lidah api, dan sebagainya merupakan cerita dari penyatuan tiga jagad, yaitu Tribawana. Visualisasi pada batik seratan citra Semen ini merupakan gambaran adanya jagad mikro atau Mikrokosmos, seperti rumah, dalam bahasa Jawa disebut dengan ndalem, sedangkan untuk sulur-sulur, dedaunan, binatang sebagai jagad makro atau Makrokosmos, lalu kemudian cahayanya dalam bentuk sayap-sayap yang melambangkan kendaraan yang ditumpangi Dewa Wisnu. Deskripsi citra Semen, sebagai bersemi dan tumbuh selain dalam visualisasinya yang berkenaan dengan Tribawana, juga dapat dijadikan pemaknaan untuk diaplikasikan bahwa Tribawana sebagai bagian dari budaya. Hal ini dapat 
direalisasikan pada proses kreatif berkarya seni batik sebagai salah satu wujud pengembalian akar tradisi, untuk mengembangkan seni batik secara lebih luas dalam menyikapi seni batik berikutnya, baik batik modern, kontemporer, maupun lainnya. Tradisi tidak membatasi dalam kreativitas, tetapi menjadi akar dan roh yang kuat dalam berkarya seni.

\section{PENUTUP}

Tribawana merupakan konsep kreativitas berkarya yang terdiri atas tiga dimensi alam, yaitu jagad alit (Mikrokosmos), jagad ageng (Makrokosmos), dan Sumber Kreativitas. Tiga hal ini, sebagai aspek pandangan kosmologi budaya Jawa. Konsep Tribawana sebagai bagian dari akar budaya Jawa Kuno memiliki relevansi dan ketepatan untuk diterapkan pada proses kreatif dalam berkarya seni batik, dengan kembali kepada tradisi dari mana batik berasal.

Pelaksanaan Konsep Tribawana dalam proses kreatif di Rumah Budaya Babaran Segaragunung terdiri atas proses pemahaman dalam bentuk pengetahuan dan latihan bersama atau praktik. a) Proses pembelajaran pengetahuan, memberikan kesadaran bahwa seni batik merupakan ilmu yang multidisiplin, yang dalam proses pemahaman dan penginterpretasian visual batik melibatkan pandangan perspektif budaya, yaitu budaya Jawa Kuno, dari aspek bahasa digunakan pada proses penyampaian dan proses pembacaan teks, yaitu bahasa Sanskerta, bahasa Indonesia, dan bahasa Jawa Kuno melalui pendekatan ekologi Jawa dengan pendekatan pada alam dan lingkungan, memberikan pengetahuan baru tentang alam yang dihubungkan dengan kebudayaan Jawa, baik dari kebiasaan perlakuan orang Jawa terhadap alam, maupun bahasa atau pengenalan nama tumbuhan berdasarkan bahasa Jawa Kuno; b) latihan bersama atau praktik memberikan pengetahuan, sejauh mana dapat menyikapi, dan mengontrol dalam mengatur keseimbangan diri dengan alam, dan setiap orang akan memiliki pengalaman unik, dan tidak ada keseragaman tergantung kepada potensi diri. Memberikan gambaran berpikir tidak terpusat hanya dalam kepala, tetapi melibatkan kepekaan rasa dan penghayatan secara penuh dengan ikut lebur di dalamnya mampu melatih berpikir secara analitis, kritis, dan kreatif.

Dalam batik seratan citra Semen terdapat ketiga aspek: Mikrokosmos, Makrokosmos, dan sumber kreativitas yang divisualisasikan.

\section{DAFTAR PUSTAKA}

Hariwijaya. 2013. Semiotika Jawa: Kajian Makna Falsafah Tradisi. Yogyakarta: Paradigma Indonesia.

Pujileksono, Sugeng. 2015. Pengantar Antropologi: Memahami Realitas Sosial Budaya. Malang: Intrans Publishing.

Sumodiningrat, Gunawan \&Ari Wulandari. 2014. Pitutur Luhur Budaya Jawa. Yogyakarta: Narasi.

Kusrianto, Adi. 2013. Batik Filosofi, Citra \& Kegunaan. Yogyakarta: C.V Andi Offset.

Yin, Robert K. 1987. Case Study Research: Design and Methods atau Studi Kasus: Desain dan Metode. Terjemahan Mudzakir Djaudi. 2015. Jakarta: PT Raja Grafindo Persada.

\section{Informan}

Manu W. Padmadipura (63 th), ahli Filologi dan Kebudayaan Jawa

Agung Harjuno (61 th), ahli bidang Filsafat Kebudayaan

Agus Ismoyo (59 th), Seniman Batik dan Budayawan

Nia Filliam (63 th), Seniman Batik, Pengkaji dan Pemerhati Budaya

Legi (27 th), Seniman dan Akademisi

Okta (23 th), Seniman dan Akademisi 